\title{
Social and obstetric inequalities and vaccination in pregnant women
}

\author{
Desigualdades sociais e obstétricas e vacinação em gestantes \\ Desigualdades sociales y obstétricas y vacunación en gestantes
}

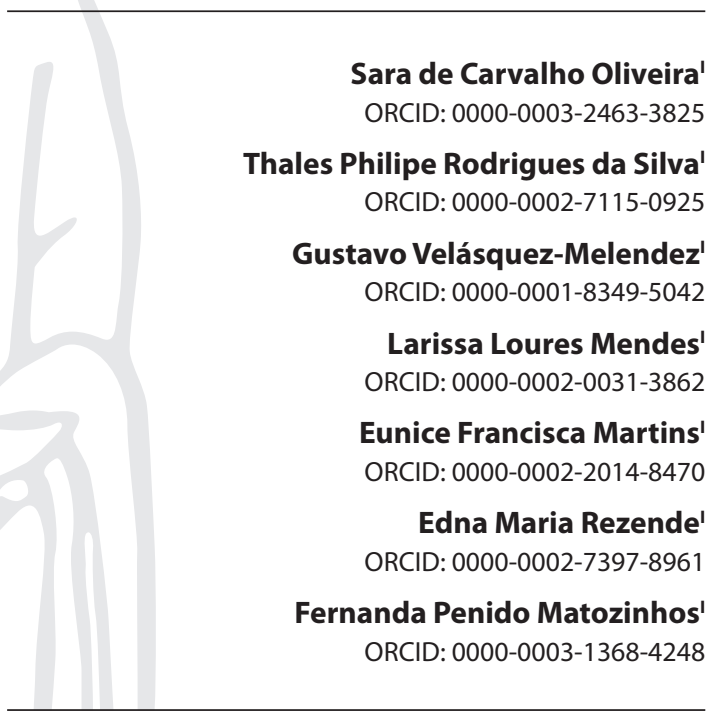

'Universidade Federal de Minas Gerais. Belo Horizonte, Minas Gerais, Brazil.

How to cite this article: Oliveira SC, Silva TPR, Velásquez-Melendez G, Mendes LL, Martins EF, Rezende EM, et al. Social and obstetric inequalities and vaccination in pregnant women. Rev Bras Enferm. 2020;73(Suppl 4):e20190099. doi: http://dx.doi.org/10.1590/0034-7167-2019-0099

\section{Corresponding author:}

Fernanda Penido Matozinhos E-mail: nandapenido@hotmail.com

EDITOR IN CHIEF: Dulce Aparecida Barbosa ASSOCIATE EDITOR: Margarida Vieira

Submission: 02-12-2019

Approval: 05-11-2020

\section{RESUMO}

Objetivos: analisar a associação do nível socioeconômico e características obstétricas com registro vacinal de gestantes. Métodos: estudo transversal, realizado com 480 puérperas. Foi considerada, como variável dependente, a vacinação de gestantes; e como variáveis independentes: idade, cor de pele, escolaridade, união estável, trabalho remunerado e número de consultas no pré-natal. Associação entre as variáveis foi verificada por meio de modelo de regressão de Poisson. Resultados: das 480 cadernetas de gestantes, 10,63\% possuíam informações da vacinação contra hepatite $B ; 31,46 \%$ para o tétano; e, para influenza, observou-se ausência de registro em $90 \%$ das cadernetas. Houve associação de trabalho remunerado e número de consultas realizadas no prénatal com vacinação contra hepatite $B$. Conclusões: menores proporções de ausência de vacinação ocorreram em mulheres que estavam no mercado de trabalho e que realizaram maior número de consultas de pré-natal. Isso sugere que desigualdades socioeconômicas podem interferir na vacinação de gestantes nos serviços de saúde.

Descritores: Vacinação; Cuidado Pré-Natal; Gestantes; Disparidades nos Níveis de Saúde; Iniquidade.

\section{ABSTRACT}

Objectives: to analyze the association of socioeconomic level and obstetric characteristics with vaccine registration of pregnant women. Methods: cross-sectional study, performed with 480 women in puerperal. Vaccination of pregnant women was considered a dependent variable and as independent variables were age, skin color, education, steady union, paid work, and number of prenatal consultations. Association between variables was verified by the Poisson's regression model. Results: from 480 pregnant women's health cards, $10.63 \%$ had information on hepatitis B vaccination; $31.46 \%$ for tetanus; and $90 \%$ of the health cards had not register for influenza. There was an association of paid work and number of prenatal consultations with hepatitis B vaccination. Conclusions: lower percentages in absence of vaccination occurred in women who were in the job market and had a higher number of prenatal consultations. This suggests that socioeconomic inequalities may interfere with the vaccination of pregnant women in health services.

Descriptors: Immunization; Prenatal Care; Pregnant Women; Health Status Disparities; Iniquity.

\section{RESUMEN}

Objetivos: analizar la relación del nivel socioeconómico y características obstétricas con registro de vacunación de gestantes. Métodos: estudio transversal, realizado con 480 puérperas. Ha sido considerada, como variable dependiente, la vacunación de gestantes; y como variables independientes: edad, color de piel, escolaridad, unión estable, trabajo remunerado y número de consultas en el prenatal. Relación entre las variables ha sido verificada por medio de modelo de regresión de Poisson. Resultados: de las 480 libretas de gestantes, 10,63\% poseían informaciones de la vacunación contra hepatitis $B ; 31,46 \%$ para el tétanos; $y$, para influenza, se observó ausencia de registro en $90 \%$ de las libretas. Hubo relación de trabajo remunerado y número de consultas realizadas en el prenatal con vacunación contra hepatitis B. Conclusiones: menores proporciones de ausencia de vacunación ocurrieron en mujeres que estaban en el mercado de trabajo y que realizaron mayor número de consultas de prenatal. Eso sugiere que desigualdades socioeconómicas pueden interferir en la vacunación de gestantes en los servicios de salud.

Descriptores: Vacunación; Cuidado Prenatal; Gestantes; Disparidades en los Niveles de Salud; Iniquidad. 


\section{INTRODUCTION}

Public policies directed at pregnant women are of the utmost importance to ensure the quality of assistance provided to this population group ${ }^{(1)}$. In this context, the National Immunization Program (PNI) stands out by contributing to the improvement of quality of life and increase life expectancy due to reduction, control or eradication of certain preventable diseases ${ }^{(2-3)}$.

The Brazilian pregnant woman's vaccination calendar has been increasingly expanded and improved. Vaccines against diphtheria and tetanus (dT), triple acellular bacterial (against diphtheria, tetanus and pertussis [dTpa]), recombinant hepatitis $B$ vaccine and, seasonally, influenza vaccine are considered basically necessary for maternal and child health ${ }^{(3-4)}$.

Vaccination, especially in pregnant woman, is performed at a time of great concern for the patient, since she feels responsible for the life of the fetus she is generating ${ }^{(5)}$. In addition to this concern, a previous study demonstrated a higher rate of vaccination in pregnant women who: worked as health professionals, had a higher level of education, higher monthly family income, routine medical exams, and premarital exams ${ }^{(6)}$. Another study evidenced that women in higher economic class had more chances of being immunized ${ }^{(7)}$.

Currently, despite principles of universal access to prenatal care, there are still social, economic, and obstetric care inequalities in the scope of preventive health actions ${ }^{(8-10)}$ and, therefore, in this scenario, inequalities in the vaccination of pregnant women. Vaccination coverage is below expected in certain population subgroups, which is the result from the high persistent social inequality in the country and from the sum of social and obstetric inequalities ${ }^{(11-12)}$. Iniquities in health care are defined when social, economic or geographical differences promote unequal access, or lack of access, to human rights ${ }^{(13)}$. Those are essentially unnecessary and avoidable, since they are based on social relations, marked by unequal power (socio-cultural and economic) and technological (lack of knowledge or technology to confront diseases) ${ }^{(14)}$. They are the result of how society is organized ${ }^{(15)}$ and constitute unequal opportunities arising from social stratification, generated by the individual income, social and cultural condition, housing conditions and employment, as well as other factors such as race and gender ${ }^{(16-17)}$.

In low and middle-income countries, low proportions of immunization predominated in poorer families and children of mothers with low levels of education ${ }^{(11,18)}$, especially due to unequal access to health services generated by social stratification $(12,19)$. In Brazil, socioeconomic status and access to health services have proven to be determinant factors for higher vaccination coverage in the gestational period ${ }^{(20-22)}$.

Several studies indicate that marginalized groups in society and in poverty have a higher occurrence of negative health outcomes or inadequate health conditions ${ }^{(11-12,18,20)}$. The hypothesis of this study is that social inequalities determine low coverage of access to health services and, specifically, standardized interventions or actions, such as vaccination in pregnant women. To our knowledge, there are few recent studies that show the increased vaccine coverage associated with factors such as: vaccine acceptability, access to information, socioeconomic status, and education ${ }^{(12,22-23)}$. Other studies found no association between socio-demographic factors (age, skin color, marital status, education, among others) and higher percentage of vaccination $^{(1,24)}$.

In this way, this work can contribute with subsidies to health administrators for planning and implementation of measures aimed at improving maternal and child health, since it addresses complementary results to those of the studies discussed, in addition to contributing to the greater recognition by the authorities of the importance of vaccination in pregnant women.

\section{OBJECTIVES}

To analyze associating socioeconomic levels and obstetric characteristics with pregnant women's vaccine registry.

\section{METHODS}

\section{Ethical Aspects}

This study was approved by the Ethics Committee of the Federal University of Minas Gerais and the Ethics Committees of the maternity hospitals involved. Data collection was initiated after pregnant women signed the Informed Consent Term.

\section{Design, place, and period of study}

This is a cross-sectional observational study, developed with data from the survey: "Born in Belo Horizonte: Survey on Childbirth and Birth", conducted in seven maternity hospitals that serve the public health network and four maternity hospitals that serve the supplementary health care network in Belo Horizonte, Minas Gerais. This survey used the same sampling method, logistics and material resources as the nationwide study entitled "Born in Brazil: Survey on Childbirth and Birth"(25-26).

The sample consisted of puerperals who had children born alive in 2011, in hospitals with 500 or more live births in 2007, according to the Information System for Live Births (SINASC). The sampling process took place in three stages: selection of the participating hospitals, reverse sampling method and random selection of puerperals ${ }^{(25-26)}$.

\section{Population, inclusion criteria}

For the present study, 480 women were admitted after having given birth in the selected maternity wards. They were included because they had the pregnant woman's health card at the time of their admission.

\section{Study protocol}

The data collection took place from 2011 to 2013, by interviewing puerperal women after labor and included data from medical records at that moment. It is worth noting that all stages of data collection were carried out by nurses previously trained for this purpose.

The data were obtained from a standardized questionnaire with identification variables, sociodemographic, life habits, 
nutritional information, clinical and obstetric background, and health plan variables.

For the construction of the outcome variable, the presence of vaccination was observed in the prenatal cards of puerperal women. Data were obtained from the vaccines applied, number of doses, and serological tests. Those were the considered vaccinations for pregnant women: hepatitis B vaccine, tetanus vaccine, and influenza vaccine ${ }^{(3)}$. It should be noted that the presence of vaccine registration on the prenatal card was considered an indirect measure of immunization of the pregnant woman. The absence of registration was adopted in the outcome variable; for each vaccine evaluated it was used code 0 (presence of registration) and 1 (absence of registration).

Regarding socio-demographic, economic and obstetric variables, we considered: age, skin color, education, paid work, steady union, and number of prenatal consultations.

\section{Analysis of the results and statistics}

It was performed analysis for each type of vaccine received, considering number of doses and form of application related to each recommended vaccination procedure ${ }^{(3)}$.

It was used the Stata program, version 14.0. The difference between the vaccination proportions was tested using Pearson's chi-square and Fisher's exact test; and for variables with more than two categories that had statistical difference in these tests, the analysis was performed with Bonferroni's correction.

For the continuous variable (number of consultations performed at prenatal), after checking the symmetry of distribution by the Shapiro-Wilk test, the results were presented by means of median and interquartile range (IQR).

Finally, Poisson regression was used to estimate the parameters of interest: gross and adjusted by age, education, skin color and gestational age at delivery. It should be noted that when this regression model is applied to binominal data, the error for relative risk can be overestimated, considering that the variance of the Poisson distribution increases progressively, while the variance of the binomial distribution has its maximum value when the prevalence is 0.5 . To correct this problem, the robust variance estimator is used to obtain results similar to those obtained with the use of Mantel-Haenszel statistics, when the covariable of interest is categorical ${ }^{(27)}$.

To build the multivariate regression model, it was adopted the backward method; and all variables of interest at a level of statistical significance lower than $20 \%$ were included in the bivariate analysis, being removed one by one. It is noteworthy that theoretical criteria were also considered in this study ${ }^{(18)}$. The Hosmer-Lemeshow test was used to verify the adjustment of the final model. The gross and adjusted prevalence ratios were presented, and $95 \%$ confidence intervals were calculated, considering a level of significance of 0.5 in all analytical procedures.

\section{RESULTS}

The majority of women (73.54\%) in the study were between 19 and 35 years old, self-reported brown/mulatto skin color
(63.13\%), had completed high school (51.36\%), lived with some kind of partner (70.21\%) and had paid work (51.67\%). In addition, the median number of prenatal consultations was 8 (Table 1).

Table 1 - Percentage distribution and 95\% confidence interval of socioeconomic and obstetric variables, Belo Horizonte, Minas Gerais, Brazil, 2011-2013

\begin{tabular}{lcc}
\hline Variables & $\mathbf{n}(\%)$ & IC 95\% \\
\hline Age (years) & & \\
$\quad<20$ & $53(11.04)$ & $8.52-14.18$ \\
$\quad$ Between 20 and 34 & $353(73.54)$ & $69.39-77.30$ \\
$\quad \geq 35$ & $74(15.42)$ & $12.44-18.94$ \\
Color of skin & & \\
$\quad$ White & $124(25.83)$ & $22.10-29.95$ \\
$\quad$ Black & $44(9.17)$ & $6.88-12.10$ \\
$\quad$ Brown/dark/mulatto & $303(63.13)$ & $58.69-67.34$ \\
$\quad$ Asian/eastern/indígenous & $9(1.87)$ & $0.97-3.57$ \\
Education & & \\
$\quad$ College Education & $69(14.41)$ & $11.52-17.85$ \\
$\quad$ High School & $246(51.36)$ & $46.86-55.82$ \\
$\quad$ None + primary school & $164(34.23)$ & $30.10-38.62$ \\
Steady Union & & \\
$\quad$ Do live with partner & $337(70.21)$ & $65.94-74.14$ \\
$\quad$ Does not live with partner & $143(29.79)$ & $25.85-34.05$ \\
Paid work & & \\
$\quad$ Yes & $248(51.67)$ & $47.17-56.12$ \\
$\quad$ No & $232(48.33)$ & $43.87-52.82$ \\
Number of pre-natal consultations* & $8(7-10)$ & \\
\hline & & \\
\hline
\end{tabular}

Note: IC95\% - 95\% confidence interval; * Median (IQ).

From the total number of pregnant women evaluated, $10.63 \%$ had a vaccination record for hepatitis $B$ and $31.46 \%$ a vaccination record for tetanus. In relation to influenza, $90 \%$ of pregnant women had no record whatsoever (data not shown).

Table 2 indicates the percentages of vaccination recommended during pregnancy. Regarding hepatitis B vaccine, the variables related to education, paid work, and number of prenatal consultations showed a statistically significant difference.

As for tetanus vaccine, there was also a statistically significant difference in paid work during pregnancy and in the number of prenatal consultations. Finally, for influenza vaccine, the number of consultations also showed an association with the presence of registration (Table 2).

Table 3 shows values of association measures (RP) using Poisson regression models, adjusted by age, education, skin color and maternal gestational age.

The prevalence of non-vaccination in women with paid work was 0.91 times over the prevalence of women who had not paid work, controlled by other variables presented in the model. Moreover, in relation to the number of consultation(s) completed during the prenatal period, it was observed that the increase of 1 consultation in this period reduced the prevalence of non-vaccination of pregnant women against hepatitis B by $2 \%$, adjusted for the other variables.

It is worth noting that in the adjusted regression model using tetanus and influenza vaccines, none of the explanatory variables remained statistically significant. 
Table 2 - Percentage of vaccination according to social inequalities and obstetric care inequalities, Belo Horizonte, Minas Gerais, Brazil, $2011-2013$

\begin{tabular}{|c|c|c|c|c|c|c|}
\hline & $\begin{array}{c}\text { Hepatitis B } \\
\text { Vaccination } \\
\text { present } \\
\text { n (\%) }\end{array}$ & $p$ value & $\begin{array}{l}\text { Vaccine } \\
\text { Tetanus* } \\
\text { Vaccination } \\
\text { present } \\
\text { n (\%) }\end{array}$ & $\begin{array}{l}\text { ainst: } \\
p \text { value }\end{array}$ & $\begin{array}{c}\text { Influenza } \\
\text { Vaccination } \\
\text { present } \\
\text { n (\%) }\end{array}$ & $p$ value \\
\hline Age (years) & & $0.499^{\dagger}$ & & $0.702^{\dagger}$ & & $0.503^{\ddagger}$ \\
\hline$<20$ & $7(13.21)$ & & $14(26.42)$ & & $4(7.55)$ & \\
\hline Between 20 and 34 & $34(9.63)$ & & $113(32.01)$ & & $34(9.63)$ & \\
\hline$\geq 35$ & $10(13.51)$ & & $24(32.43)$ & & $10(13.51)$ & \\
\hline Color of skin & & $0.162^{\S}$ & & $0.660^{\S}$ & & $0.387^{\S}$ \\
\hline White & $19(15.32)$ & & $37(29.84)$ & & $16(12.90)$ & \\
\hline Black & $2(4.55)$ & & $11(25.00)$ & & $2(4.55)$ & \\
\hline Brown/dark/mulatto & $29(9.57)$ & & $101(33.33)$ & & $29(9.57)$ & \\
\hline Asian/eastern/indígenous & $1(11.11)$ & & $2(22.22)$ & & $1(11.11)$ & \\
\hline Education" & & $0.045^{\dagger}$ & & $0.636^{+}$ & & $0.454^{\dagger}$ \\
\hline College Education ${ }^{\mathrm{A}}$ & $13(18.84)$ & & $25(36.23)$ & & $9(13.04)$ & \\
\hline High School ${ }^{A B}$ & $25(10.16)$ & & $75(30.49)$ & & $26(10.57)$ & \\
\hline None + primary school ${ }^{\mathrm{B}}$ & $13(7.93)$ & & $50(30.49)$ & & $13(7.93)$ & \\
\hline Steady Union & & $0.093^{\dagger}$ & & $0.053^{\dagger}$ & & $0.272^{\dagger}$ \\
\hline Do live with partner & $41(12.17)$ & & $115(34.12)$ & & $37(10.98)$ & \\
\hline Do not live with partner & $10(6.99)$ & & $36(25.17)$ & & $11(7.69)$ & \\
\hline Paid Work & & $0.023^{\dagger}$ & & $0.003^{\dagger}$ & & $0.201^{\dagger}$ \\
\hline No & $17(7.33)$ & & $58(25.00)$ & & 19(8.19) & \\
\hline Yes & $34(13.71)$ & & $93(37.50)$ & & 29(11.69) & \\
\hline No of pre-natal consultations ${ }^{\ddagger}$ & $10(8-12)$ & $<0.001$ & $9(7-10)$ & 0.042 & $10(9-11)$ & $<0.001$ \\
\hline
\end{tabular}

Notes: *Includes VAT, $d T$ and dTpa vaccines. ${ }^{\dagger}$ performed Pearson chi-square test; $p$ value in bold $\leq 0.05 .{ }^{\ddagger}$ Teste Mann-Whitney, Median (IQ); $p$ value in bold $<0.05 .{ }^{\S}$ performed Fisher's exact test; $p$ value in bold $<0.05$. $\| p<0.05$ (post hoc associated with Bonferroni correction, $p<0.016$ ). Equal letters mean similarity between the proportions.

Table 3 - Prevalence ratios and adjusted confidence intervals for the absence of hepatitis B vaccination, Belo Horizonte, Minas Gerais, Brazil, 2011-2013

\begin{tabular}{lcc}
\hline Variables & \multicolumn{2}{c}{$\begin{array}{c}\text { Absence of vaccination } \\
\text { for hepatitis B }\end{array}$} \\
& $\begin{array}{c}\text { Gross Model } \\
\text { PR (Cl 95\%) }\end{array}$ & $\begin{array}{c}\text { Adjusted Model* } \\
\text { PR (Cl 95\%) }\end{array}$ \\
\hline $\begin{array}{l}\text { Paid work } \\
\text { No } \\
\text { Yes }\end{array}$ & 1 & 1 \\
Number of pre-natal consultations & $0.97(0.96-0.98)$ & $0.98(0.96-0.99)$ \\
\hline
\end{tabular}

Notes: $P R$ - prevalence ratio; $95 \% \mathrm{Cl}$ - 95\% confidence interval; * Model adjusted for age, education, skin color and gestational age; Hosmer-Lemeshow $p$-value $>0.05$.

\section{DISCUSSION}

This study analyzed the connection between social and obstetric inequities and vaccination. From the data of 480 pregnant women health cards analyzed in the study, it was discovered exceptionally low rates of vaccination registration, especially for hepatitis $B$ and influenza. It was also found that paid work and the number of prenatal consultations were associated with a lower proportion of vaccination absenteeism in pregnant women. A higher proportion of hepatitis B vaccination was observed for women with higher education (when compared to pregnant women with no education or primary education). In this context of influence of social and obstetric inequalities in association with hepatitis $B$ vaccination, a survey conducted in the city of São Paulo found no association of sociodemographic and obstetric variables with a complete vaccine regimen in the puerperium for hepatitis $B$ and $d T$ vaccines ${ }^{(1)}$.

Another study, conducted in the city of Pelotas, State of Rio Grande do Sul, also did not point out an association between sociodemographic factors (age, education, marital status and number of pregnancies) and lack of access to hepatitis B vaccine.
However, this cross-sectional study is limited by lack of official records of $\mathrm{HBV}$ in pregnant women in the municipality and also because there is a memory bias, that is, some pregnant women may not remember having been vaccinated ${ }^{(24)}$. Another descriptive and cross-sectional study, conducted in the city of Jundiai, State of São Paulo, did not show any association of sociodemographic and gestational variables with the hepatitis $B$ vaccine ${ }^{(28)}$.

However, a survey conducted in Mayotte Island, Indian Ocean, found that the highest educational level was positively associated with the presence of vaccination for hepatitis $B$ virus (HBV) (23). In addition, a cross-sectional study nested to a birth cohort, conducted in the city of São Luís, State of Maranhão, revealed that low education was associated with a high rate of inadequate prenatal care, which directly interferes with the performing of proper vaccination $^{(8)}$.

Health care systems, quality of services and access to them, as well as the best technologies in health care, appear to be unequally distributed among the people and groups that make up society. The social differences encountered in this study (such as whether or not to have paid work) affect human health, especially maternal health, as well as reaching specific groups, either through lack of access or difficult access to services offered by priority medical devices, especially the hepatitis B vaccine ${ }^{(14)}$.

In this context, although universalization of access to prenatal care is well-known by Brazilian populace, social and obstetric inequalities still persist in that population ${ }^{(8)}$. Low education and strong social differences (proxy from the less favored economic class) point to a loss in the quality of health care provided to pregnant women ${ }^{(8)}$.

Social inequalities, such as paid work - education proxy - are a strong determinant for prenatal "adequacy". To carry out a paid work is an important factor in prenatal adequacy, since similar 
studies show an association between women working and the early start of prenatal consultations; and more number of prenatal consultations are associated with a greater chance of maternal immunization ${ }^{(29)}$. This finding coincides with other studies, where the fact that women do work has a positive influence on access to prenatal care and health caretaking, due to the more information and associated with a higher level of education ${ }^{(12,23-24,27,30)}$. It is observed that higher numbers of prenatal consultations were associated with better records for such vaccine. The health caretaking provided during the prenatal period is directly related to pregnant women vaccination, and is a significant factor affecting directly vaccination coverage ${ }^{(31)}$. The knowledge learned by pregnant women about the protection afforded by the vaccine during the prenatal period is associated with better rates of vaccination coverage ${ }^{(22)}$.

The health care system and the organization of health caretaking actions by services must be considered a fundamental element of the decision process and, consequently, the acceptance of pregnant women, in addition to be one of the responsible for better vaccination rates. In low-educated and low-income pregnant women, barriers to access may determine of low rates of vaccination coverage ${ }^{(32)}$. The access barrier and segregation of those groups imply lack of early search for health care service by pregnant women, impacting maternal morbidity, not to mention the worsening of perinatal outcomes, since it makes it difficult to identify early necessary interventions ${ }^{(33)}$.

Social segregation by specific groups derived from social inequalities interferes in prenatal care and, in turn, in the pregnant woman vaccination. Thus, it's more coherent to consider an interrelationship between these two types of assistance than to understand them separately ${ }^{(34)}$. Consequently, women in paid employment are more likely to seek health assistance because work is associated with higher education and more information, as well as higher income. A cohort study by the Center for Disease Control and Prevention (CDC) in Minnesota, in the United States, found similar results, i.e. possible obstetric and social inequalities for women, such as access to adequate prenatal care and the recommended number of consultations associated with larger vaccination coverage; it also varied according to the mother's race and country or region of birth, in addition to other demographic characteristics $^{(35)}$.

A review on the challenges and opportunities for better vaccine coverage for pregnant women highlights studies in which pregnant women with lower income, less education and belonging to racial/ethnic minority groups have lower vaccination prevalence ${ }^{(12)}$. Therefore, to improve the quality of prenatal care and, consequently, increase the proportions of a complete vaccination scheme, it is paramount to disseminate information based on scientific evidence, and professionals from the multiprofessional team are encouraged to follow guidelines on vaccination and recording registries.

Vaccination is a priority, effective and strategic action of the Primary Health Care Policy $(\mathrm{PHC})^{(36)}$. Immunization programs contribute to improvement of quality and increase of life expectancy worldwide due to the reduction, control or eradication of preventable diseases ${ }^{(2)}$, in addition to contributing to the reduction of health-related inequities. In this context, the Community Health Agents Program (PACS) has become a means of minimizing those inequities, since it contributes to production of information and subsequent situational diagnosis in health; in addition to identifying and referring pregnant women to prenatal care, following the periodic vaccination by the Pregnant Women's Card ${ }^{(37)}$. The Family Health Strategy later reoriented the assistance model in the Brazilian public health system, helping in a survey gathering information to encourage universal coverage and having health surveillance as a principle ${ }^{(37)}$. Directed to health care in the gravidic-puerperal cycle, the Health's Prenatal and Birth Humanization Program was launched by the Ministry of Health in $2000^{(38)}$ with the purpose of regulating the activities developed in prenatal care and recommending criteria to evaluate the assistance provided, including vaccination ${ }^{(39)}$.

\section{Limitations of the study}

Finally, some limitations in this study should be recognized, such as the possibility of underreporting the occurrence of these vaccines, i.e. pregnant women may have been vaccinated, but the procedure may not have been properly documented in the pregnant woman's health card, implying possible double vaccination in those women or not protection against preventable diseases by this method. Another possible limitation concerns the possible reverse causality associated with paid work, since vaccination could have occurred before pregnant women started working.

\section{Contributions to Nursing and Healthcare}

Despite the limitations highlighted, this work advances in the perspective of data analysis on women's health, yet not fully explored, demonstrating that there are inequities associated with pregnant women vaccination.

Based on the above considerations, it is necessary to reflect on the importance of nurse's role nurse while ensuring quality care, and taking into account the importance of the impact of guidelines based on scientific evidence guided by the development of a bond between the caretaking user and the nursing record, in order to ensure health promotion and prevention of diseases during pregnancy. With help of health policies aiming health care inclusion and promotion, the nurse should, by welcoming the pregnant woman into the service, deal with the existing vulnerabilities, carrying out active searches when necessary as well as integral and individualized attention, so that the quality of care may be guaranteed and there is equity in the access to health for the entire population.

Acceptance of the vaccine is undoubtedly a key factor in achieving higher rates of vaccination, and may not occur due to lack of knowledge about disease susceptibility, concerns about vaccine safety and side effects, distrust in health care professionals, and inadequate access to care ${ }^{(17)}$.

\section{CONCLUSIONS}

From the analyses of this study, it can be inferred that lower proportions of absence of vaccination occur in women who are in the job market and in those who perform more prenatal consultations. This suggests that socioeconomic inequalities 
may interfere with the provision of vaccination services among pregnant women. It has been shown that paid work during prenatal care and higher number of prenatal consultations are associated with a higher prevalence of registration for recombinant hepatitis B vaccine. Furthermore, the deficiency of registration, and therefore the absence of vaccination, is greater in the most vulnerable groups, suggesting inequity in health.

Therefore, women in more vulnerable situations need greater care in order to receive the same assistance than other women; and when this care is not offered, it can be inferred that their vulnerability factors are considered inequalities that affect the assurance of health assistance, characterizing health inequities.

\section{FUNDING/ACKNOWLEDGMENT}

JGVM thanks Fapemig (grant funding PPM0071316). Thanks also to Núcleo de Estudos e Pesquisa em Vacinação (NUPESV - CNPq) for its support in the completion of this study.

\section{REFERENCES}

1. Rocha BCC, Carvalheira APP, Ferrari AP, Tonete VLP, Duarte MTC, Parada CMGL. Immunization coverage and associated factors of women who have recently given birth in a city in São Paulo state. Ciênc Saúde Coletiva [Internet]. 2016 [cited 2017 Jun 20];21(7):2287-92. doi: $10.1590 / 1413-81232015217.16862015$

2. Perrett KP, Nolan TM. Immunization during pregnancy: impact on the infant. Paediatr Drugs [Internet]. 2017 [cited 2017 Jun 20];19(4):31324. Available from: https://www.ncbi.nlm.nih.gov/pubmed/28510067. doi: 10.1007/s40272-017-0231-7

3. Ministério da Saúde (BR). Secretaria de Vigilância em Saúde. Departamento de Vigilância das Doenças Transmissíveis. Manual de Normas e Procedimentos para Vacinação. Brasília: MS [Internet]; 2014 [cited 2017 Jun 20]. Available from: http://bvsms.saude.gov.br/bvs/publicacoes/ manual_procedimentos_vacinacao.pdf

4. Ministério da Saúde (BR). Secretaria de Vigilância em Saúde. Departamento de Vigilância Epidemiológica. Coordenação Geral do Programa Nacional de Imunizações. Informe técnico para implantação da vacina adsorvida difteria, tétano e coqueluche (Pertussis Acelular) Tipo adulto - dTpa[Internet]. Brasília: MS; 2014 [cited 2017 Jun 20]. Available from: http://portalarquivos.saude.gov.br/images/pdf/2015/ junho/26/Informe-T--cnico-dTpa-2014.pdf

5. Wilson RJ, Paterson $\mathrm{P}$, Jarrett C, Larson HJ. Understanding factors influencing vaccination acceptance during pregnancy globally: a literature review. Vaccine [Internet]. 2015 [cited 2017 Jun 20];33(47):6420-6429. doi: 10.1016/j.vaccine.2015.08.046

6. Chan OK, Suen SSH, Lao TTH, Leung VKT, Yeung SW, Leung TY. Determinants of hepatitis B vaccine uptake among pregnant Chinese women in Hong Kong. Int J Gynecol Obstetr[Internet]. 2009 [cited 2017 Jun 20];106(3):232-5. doi: 10.1016/j.ijgo.2009.03.043

7. Salleras L, Domínguez A, Bruguera M, Plans P, Espuñes J, Costa J et al. Seroepidemiology of hepatitis B virus infection in pregnant women in Catalonia (Spain). J Clin Virology[Internet]. 2009 [cited 2017 Jun 20];44(4):329-332. doi: 10.1016/j.jcv.2009.01.002

8. Goudard MJF, Simões VMF, Batista RFL, Queiroz RCS, Alves MTSSB, Coimbra LC, et al. Inadequacy of the content of prenatal care and associated factors in a cohort in the northeast of Brazil. Ciênc Saúde Coletiva [Internet]. 2016[cited 2017 Jun 20];21(4):1227-38. doi: 10.1590/1413-81232015214.12512015

9. Ministério da Saúde (BR). Pesquisa Nacional de Demografia e Saúde da Criança e da Mulher: PNDS 2006: Dimensões do Processo Reprodutivo e da Saúde da Criança [Internet]. 2009[cited 2017 Jun 20]. Available from: http://bvsms.saude.gov.br/bvs/publicacoes/pnds_crianca_mulher.pdf

10. Viellas EF, Domingues RMSM, Dias MAB, Gama SGN, Theme FMM, Costa JV, et al. Prenatalcare in Brazil. Cad Saúde Pública [Internet]. 2014[cited 2017 Jun 20];30(Suppl-1):S85-S100. doi: 10.1590/0102-311X00126013

11. Breilh J. Lastres 'S' de la determinación de la vida: 10 tesis hacia una visión crítica de la determinación social de la vida y la salud. In: Nogueira RP. (Org.). Determinação social da saúde e reforma sanitária. Rio de Janeiro: Centro Brasileiro de Estudos de Saúde. 2010. p. 87-125.

12. MacDougall DM, Halperin SA. Improving rates of maternal immunization: Challenges and opportunities. Hum Vaccines Immunotherapeuts [Internet]. 2015 [cited 2017 Jun 20];12: 4. Available from: http://www.tandfonline.com/doi/full/10.1080/21645515.2015.1101524?src=recsys

13. Starfield B. The hidden inequity in health care. Int J Equity Health. 2011;10:15. doi:10.1186/1475-9276-10-15

14. Fiorati RC, Arcêncio RA, Souza LB. As iniquidades sociais e o acesso à saúde: desafios para a sociedade, desafios para a enfermagem. Rev Latino-Am Enfermagem [Internet]. 2016[cited 2017 Jun 20];24:e2687. doi: 10.1590/1518-8345.0945.2687

15. Bagrichevsky M, Santos-Jr VJ, Estevão A, Vasconcellos SPR. Social inequalities in health and corporal practices: a singular exercise of analysis. Saude Soc. [Internet]. 2013[cited 2018 May 12];22(2):497510. doi: 10.1590/S0104-12902013000200019

16. Whitehead M. The concepts and principles of equity and health. Int J Health Serv 1992;22:429-45. doi: 10.2190/986L-LHQ6-2VTE-YRRN

17. Sanchez RM, Ciconelli RM. Conceitos de acesso à saúde. Rev Panam Salud Publica [Internet]. 2012 [cited 2018 May 12];31(3):260-8. Available from: https://scielosp.org/pdf/rpsp/2012.v31n3/260-268/pt

18. WHO. State of inequality: childhood immunization. 2016.

19. Moraes JC, Luna EJA, Grimaldi RA. Imunogenicidade da vacina brasileira contra hepatite B em adultos. Rev Saúde Pública. 2010;44(2):353-9. doi: 10.1590/S0034-89102010000200017 
20. Barata RB, Pereira SM. Desigualdades sociais e cobertura vacinal na cidade de Salvador, Bahia. Rev Bras Epidemiol. 2013;16(2):266-77. doi: $10.1590 / \mathrm{S} 1415-790 \times 2013000200004$

21. Moraes JC, Ribeiro MCSA. Desigualdades sociais e cobertura vacinal: uso de inquéritos domiciliares. Rev Bras Epidemiol. 2008;11(Suppl-1):113-24. doi: 10.1590/S1415-790X2008000500011

22. Kfouri RA, Richtmann R. Vacinação contra o vírus influenza em gestantes: cobertura da vacinação e fatores associados. Einstein. 2013;11(1):53-7. doi: 10.1590/S1679-45082013000100010

23. Saindou M, Voirin N, Troalen D, Abaine A, Queyron PC, Ecochard R, et al. Socio-demographic and behavioral determinants of hepatitis B vaccination and infection in pregnant women on Mayotte Island, Indian Ocean. Vaccine. 2013;31(43). doi: 10.1016/j.vaccine.2013.08.047

24. Espíndola MFS, Mesenburg MA, Silveira MF. Access to hepatitis B vaccine by pregnant women attending antenatal care in Pelotas, Rio Grande do Sul State, Brazil. Epidemiol Serv Saúde. 2014;23(3):447-54. doi: 10.5123/S1679-49742014000300007

25. Vasconcellos MTL, Silva PLN, Pereira APE, Schilithz AOC, Souza Jr PRB, Szwarcwald CL. Sampling design for the Birth in Brazil: national survey into labor and birth. Cad Saúde Pública. 2014;30(Suppl):S49-58. doi: 10.1590/0102-311X00176013

26. Carmo Leal MC, Silva AAM, Dias MAB, Gama SGN, Rattner D, Moreira ME, et al. Birth in Brazil: national survey into labor and birth. Reprod Health [Internet]. 2012[cited 2018 May 12];9:15. Available from: https://reproductive-health-journal.biomedcentral.com/ articles/10.1186/1742-4755-9-15

27. Coutinho LMS, Scazufca M, Menezes PR. Methods for estimating prevalence ratios in cross-sectional studies. Rev Saúde Pública. 2008;42(6):992-8. doi: 10.1590/S0034-89102008000600003

28. Traldi MC, Teleck CF, Teixeira JQ, Fonseca MRCC. Conformity between immunization records in prenatal charts and vaccine conditions of pregnant women seen in public health services of Jundiaí-SP. Biosci J [Internet]. 2017[cited 2018 May 12];33(3):769-78. Available from: http://www.seer.ufu.br/index.php/biosciencejournal/article/viewFile/35696/20341

29. Mattos LMBB, Caiaffa WT, Rocha BR, Tonelli E. Missed opportunities for tetanus immunization of pregnant women in Juiz de Fora, Minas Gerais, Brazil. Rev Panam Salud Pública [Internet]. 2003 [cited 2018 May 12]. Available from: https://pubmed.ncbi.nlm.nih.gov/14766035/

30. Chiavarini M, Lanari D, Minelli L, Salmasi L. Socio-demographic determinants and access to prenatal care in Italy. BMC Health Serv Res [Internet]. 2014 [cited 2018 May 12];14:174. Available from: https://www.ncbi.nlm.nih.gov/pmc/articles/PMC3991890/?tool=pubmed

31. Baum S, Hitschold T, Becker A, Smola S, Solomayer E, Rody A, et al. implementation of the recommendation to vaccinate pregnant women against seasonal influenza: vaccination rates and acceptance. Geburtshilfe Frauenheilkd. 2017;77(4):340-51. doi: 10.1055/s-0043-103970

32. Berezin M, Eads A. Risk is for the rich? childhood vaccination resistance and a culture of health. Soc Sci Med. 2016;165:233-245. doi:10.1016/j.socscimed.2016.07.009

33. Corrêa CRH, Bonadio IC, Tsunechiro MA. Evaluación normativa del prenatal en maternidad filantrópica de São Paulo. Rev Esc Enferm USP. 2011;45(6):1293-300. doi: 10.1590/S0080-62342011000600003

34. Penido FP, Mendes LL, Andrade CJM, Velasquez-Melendez G. Evaluation of prenatal care: a population-based study. Rev APS [Internet]. 2014 [cited 2018 May 12];17(4):469-75. Available from: https://aps.ufjf.emnuvens.com.br/aps/article/view/2222/841

35. Centers for Disease Control and Prevention (CDC). Barber A, Muscoplat MH, Fedorowicz A. Coverage with Tetanus, Diphtheria, and Acellular Pertussis vaccine and influenza vaccine among pregnant women-Minnesota, March 2013-December 2014. MMWR Morb Mortal Wkly Rep [Internet]. 2017 [cited 2018 May 12];66:56-59. Available from: https://www.cdc.gov/mmwr/volumes/66/wr/mm6602a4. $\mathrm{htm}$ ?s_cid=mm6602a4_w

36. Siqueira LG, Martins AMEBL, Versiani CMC, Almeida LAV, Oliveira CS, Nascimento JE, et al. Avaliação da organização e funcionamento das salas de vacina na Atenção Primária à Saúde em Montes Claros, Minas Gerais, 2015. Epidemiol Serv Saúde. 2017;26(3):557-68. doi: 10.5123/ s1679-49742017000300013

37. Santos Neto ET, Oliveira AE, Zandonade E, Gama SGN, Leal MC. O que os cartões de pré-natal das gestantes revelam sobre a assistência nos serviços do SUS da Região Metropolitana da Grande Vitória, Espírito Santo, Brasil? Cad Saúde Pública. 2012;28(9):1650-62. doi: 10.1590/ S0102-311X2012000900005

38. Ministério da Saúde (BR). Pré-natal e puerpério: atenção qualificada e humanizada. Brasília: Ministério da Saúde; 2005.

39. Zanchi M, Gonçalves CV, Cesar JA, Dumith SC. Concordância entre informações do Cartão da Gestante e do recordatório materno entre puérperas de uma cidade brasileira de médio porte. Cad Saúde Pública. 2013;29(5):1019-28. doi: 10.1590/S0102-311X2013000500019 